COMPETITOR: Jurnal Pendidikan Kepelatihan Olahraga

Volume 13 Number 1 Year 2021

e-ISSN: 2657-0734 \& p-ISSN: 2085-5389

This work is licensed under a Creative Commons Attribution 4.0 International License

\title{
Making Service Level Measuring Equipment (Service Detector) In Badminton Sports
}

\author{
Ali Syafani ${ }^{1}$, Ari Subarkah ${ }^{2}$, Ika Novitaria Marani ${ }^{3 *}$ \\ ${ }^{1,2,3}$ Faculty of Sports Science / Jakarta State University / Jakarta / Indonesia \\ ${ }^{1,2,3}$ Kampus B, Jl. Pemuda, No. 10, RT.8/RW.5, Rawamangun, Kec. Pulo Gadung, East Jakarta City, \\ DKI Jakarta 13220 \\ 1a. 1 isyafani94@gmail.com, ${ }^{2}$ arytarakan2008@gmail.com, ${ }^{3}$ ikanovi1979@gmail.com
}

Received: December 10, 2020; Reviewed: January 12, 2021; Accepted: January 19, 2021;

Published: February 28, 2021

\begin{abstract}
This study aims to determine how to manufacture a service height measuring device in badminton. The research method used in this research was the Sugiyono model of research and development $(R \& D)$ with 5 stages from the nee analysis until field test. The research subjects for the tool trial were 25 referees and 50 men's doubles players who competed using a service height measuring device in badminton. The validation test used in this study is to use the expert justification test which consists of 1 expert lecturer in badminton and 2 referees who have BA certified. After the expert validation test was carried out, then the tool was tested and distributed a questionnaire about the attractiveness and convenience of the service level measuring device at the badminton branch. The result of this research is that measuring service stroke height using ultrasonic sensors is suitable for use in badminton matches to assist service judges in making decisions whether the service stroke is a fault or not. And based on the results of field trials, shows that measuring service stroke height using ultrasonic sensors is attractive and easy to use. The suggestion for this research is to find a tool that is more sensitive to distance and human motion or by using an application.
\end{abstract}

Keywords: Altitude Meter; Servis; Badminton; Sensoric.

\section{INTRODUCTION}

Badminton is a sport that uses tools, namely a racket to hit and a shuttlecock as an object that is hit over the net which divides the field into two (2) equal parts. Badminton is an individual sport that can be played by one person against one person (single) or two people against two people (double). And as an achievement sport, badminton has the characteristics of a game that requires explosive movements, lots of running movements, jumping to make punches, reflexes, speed changes direction, and also requires good hand-eye coordination (Cabello Manrique \& González-Badillo, 2003). To be able to play badminton well, a badminton player must be able to master the basic game techniques used in playing. Mastering the basic techniques well can be one of the factors 
Making Service Level Measuring Equipment (Service Detector) In Badminton Sports

Ali Syafani ${ }^{1}$, Ari Subarkah ${ }^{2}$, Ika Novitaria Marani $^{3^{*}}$

ikanovi1979@gmail.com

determining victory for a badminton player in a match. Basic techniques are the basic mastery that every player must understand and master in playing badminton (Tohar, 2005). There are four basic techniques in badminton, namely: 1) grips, 2) stances, 3) footwork, 4) strokes (Purnama, 2010). After mastering the basic techniques of holding the racket and standing position, then what is next is to master the technique of stroke.

Stroke techniques are ways of making strokes in badminton to fly the shuttlecock to the opponent's field (Grice, 2007). The basic technique of strokes consists of an overhead stroke and an underhand stroke (Tohar, 2005). The types of strokes that a player must master include serve, lob, drop shot, smash, netting, underhand, and drive "(Alhusin, 2007). One of these punch techniques, there is a punch technique which is an early sign as badminton begins. Because basically, the game of badminton begins with one of the players serving a serve shot to his opponent (Laffaye, Phomsoupha, \& Dor, 2015). And after that, both players or both pairs of players are free to direct the shuttlecock in the game area to turn off the opponent's movements and get points (Candra, 2015). Therefore, the service is a very important basic technique that a badminton player must master because the service is the initial capital to be able to win a badminton match (Zhang, Li, \& Jiang, 2013). Service stroke is a stroke that crosses the shuttlecock to the opponent's field diagonally and aims to open the game (Subardjah, 2002). In serving strokes, there are several types of badminton serves that can be performed uniquely and each type of service has its advantages and disadvantages. As for the types of service strokes, namely: short, long, flat, and flick services (Grice, 2007).

Every player must master the service blow technique well so that the opponent is not easily killed. If the mastery of this service is not good, it means that the player will not score in the game. If this happens continuously or repeatedly, it is difficult for the player to score (Eric Gillet, David Leroy, Regis Thouvarecq, 2009). Several mistakes are often made when making a service stroke, namely: the shuttlecock cannot cross the net (stuck), the position of the shuttlecock is too high on the net, or the position of the shuttlecock is outside the service line. Mistakes made when making a service blow can cause opponents to easily anticipate/turn off the service that has been done and cause harm to ourselves (Marani, 2020). The service stroke itself is made from one side of the court (left or right) across the net to the opponent's area. If the shuttlecock falls on the opponent's field that does not cross, it is declared out. The left or right position of the place to perform service is determined based on the number of points collected by the player who will do the service. The right position is for the even number of points and 
Making Service Level Measuring Equipment (Service Detector) In Badminton Sports

Ali Syafani ${ }^{1}$, Ari Subarkah $^{2}$, Ika Novitaria Marani $^{3^{*}}$

ikanovi1979@gmail.com

points is still zero (0), while the left position is for the odd number of points (https://pbdjarum.org). Each match number (single and double) has a different service area. For singles, if the shuttlecock falls on the front and side boxes it is declared out. As for doubles, if the shuttlecock falls on the front box and back box, it is declared out.

However, recently the Badminton World Federation (BWF / Badminton World Federation) issued new rules regarding the implementation of service strokes. The new rule is that the height limit at the meeting of the shuttlecock and racket head (at impact) when performing service for all players must not be higher than 115 centimeters. Where the previous rules were, the height when performing services was adjusted to the anthropometry of the body of each player, namely the lower ribs. This rule was tested at 2018 All England Championship (https://sport.tempo.co). Of course, changes to the game rules related to the height during service (during the meeting of the shuttlecock and racket head (during impact) cause new problems, especially for the referee as the person who leads the match and the service judge who is in charge of seeing whether or not the player is doing service. The service judge can decide whether the service shot by the player is considered to have violated the rules (fault) or not. Therefore, badminton referees must understand all badminton rules that are regulated in the rules of badminton games and matches set by BWF.

An understanding of badminton game rules, especially the new service regulations, is very important so that the badminton game can run according to the prevailing rules because the referee is in charge of controlling the game. The referee on duty in the field has a role to determine the quality of a match and the course of the match becomes a spectacle that can be enjoyed by the audience and does not harm the players who are competing (Akbar \& Hastjarjo, 2019). However, the task of badminton referees is not an easy matter because they must be observant of events and can make fair decisions in a fraction of a second. The decision-making mistakes made by the referee while leading will ruin the course of the match. Not only tarnishing the match, sometimes in a match if the referee makes a mistake, but there will also be several reactions from various circles, including players, line judges, coaches, officials, and supporters (Downward \& Jones, 2007). Especially in the case of service strokes, players often make service flicks that are very difficult to observe with the naked eye regarding the latest badminton game rules. Based on the description of the background of the problem above, the researcher is interested in researching the manufacture of a service height measuring device in the badminton branch. 
Making Service Level Measuring Equipment (Service Detector) In Badminton Sports

Ali Syafani ${ }^{1}$, Ari Subarkah $^{2}$, Ika Novitaria Marani $^{3^{*}}$

ikanovi1979@gmail.com

\section{METHOD}

This study aims to make a service height measuring device in badminton. The research was conducted in Jakarta and the research was carried out starting from July 2020 - December 2020. The target in this study to test the service height measurement tool was the referee who would decide on the service shot made by the player. And when testing the tool, the subjects of this study were 50 people (men's doubles) and 25 service judges at the Mami Jawa Sugar Championship which was held in December 2020. The method used in this study was Sugiyono's research and development (R\&D) model. The following are the steps in Sugiyono's R \& D model used in this research, namely:

The initial stage in this research is to determine the potential and problems of measuring service height in badminton with a preliminary study by observing and interviewing referees, coaches and players. Observations and interviews were carried out to find out whether there were obstacles when making decisions when the player made a service shot due to a change in rules. This is to find out whether there is a tool to help a service judge in deciding whether the service hit is faulted or not. To find out also whether these tools can function properly. And also to find out opinions about whether there is a need for tools other than the ones currently used.

The initial stage in this research is to determine the potential and problems of measuring service height in badminton with a preliminary study by observing and interviewing referees, coaches and players. Observations and interviews were carried out to find out whether there were obstacles when making decisions when the player made a service shot due to a change in rules. This is to find out whether there is a tool to help a service judge in deciding whether the service hit is faulted or not. To find out also whether these tools can function properly. And also to find out opinions about whether there is a need for tools other than the ones currently used.

Based on the potential and problems as well as data collection related to the manufacture of a service stroke height measuring device in the badminton branch, a design or product design for the service stroke height gauge using ultrasonic sensors is made. The manufacture of this tool uses electronic components as well as other tools that are used to assemble service blow height gauges using ultrasonic sensors.

After completing a product design and product design, the next step is the design validation stage. The purpose of expert validation is to determine the extent to which the service level measuring device is suitable for use or has useful features. Service height 
Making Service Level Measuring Equipment (Service Detector) In Badminton Sports

Ali Syafani ${ }^{1}$, Ari Subarkah $^{2}$, Ika Novitaria Marani ${ }^{3^{*}}$

ikanovi1979@gmail.com

gauges are made and rated by experts in the field of badminton, namely badminton lecturers and badminton refereeing fields. The expert validation in this study consisted of three (3) people, namely: one (1) badminton lecturer, and two (2) referees as the person who will use the product. Design validation is done by providing a review sheet for measuring service height in badminton.

After revising the designs and products provided by the experts, the next step is to test the service level gauge at the badminton branch. Product testing has the aim to find out whether the model that has been made can be used or not. It is also to find out whether the product that has been made has achieved the goals and objectives of making the product by looking at the extent to which the tool is attractive and easy to use in determining whether the service hit by the player is a fault or not. Product testing is carried out by badminton players in a game led by a referee to see how the product works.

\section{RESULTS AND DISCUSSION}

Based on the stages in research and development described above, the results of the research can be seen as follows:

To determine the potential and problems with the problems under study, it is necessary to conduct a needs analysis which is done utilizing observation and interviews with players, coaches, and referees/service judges. The results of observations and interviews found in the field show that the change in badminton game regulations, especially those related to service blows, gives difficulties for decision-makers, namely service judging whether the service hit by the player is a fault or not. Until now, PB. PBSI and Pengda have tools that are used to measure the height when making service strokes that are allowed in the game rules. However, this tool is deemed ineffective in assisting the service judge to determine whether the player's service hit is a fault or not. Based on the results of these observations and interviews, this study aims to make a service level measuring device called a service detector.

After analyzing the needs of the problems under study by conducting observations and interviews, the next stage is to collect data from observations and interviews as well as product design. Collecting data from observations and interviews is needed as a basis for making product designs. So, it can provide an idea of how the service level gauge in badminton is made. The product developed refers to the research objective, which is to 
Making Service Level Measuring Equipment (Service Detector) In Badminton Sports

Ali Syafani ${ }^{1}$, Ari Subarkah $^{2}$, Ika Novitaria Marani ${ }^{3 *}$

ikanovi1979@gmail.com

measure the height of service strokes so that the service strokes made by players are following the game rules in badminton. Based on the collection of data from observations and interviews related to the manufacture of a service blow height measuring device in the badminton branch, a design or product design for the manufacture of a service stroke height measuring device is made using ultrasonic sensors. To make a service blow height measuring device using an ultrasonic sensor, electronic components are needed, namely: Ultrasonic Sensor, Arduino Uno, Resistor, a 9-volt battery, and battery socket push button and LED, As for the tools used to make height measuring devices Service strokes are: PCB (Printed Circuit Board), solder, hot glue gun, cutting pliers, clamp pliers, light fittings, panel boxes, screwdrivers, cutters, cable insulation, and scissors. And the materials needed to make a service stroke height measuring device are: Fill glue gun, lead, pin header, cable, and battery socket.

Before the development of a service level measuring tool in the badminton branch can be tested, it needs to be validated by experts. Experts validate service stroke height gauges on badminton required during matches to get a fair decision. Researchers present 3 experts in assessing the feasibility of measuring service stroke height using ultrasonic sensors. The experts consist of 1 expert who works as a badminton lecturer in the Coaching Education Study Program, Faculty of Sports Science, State University of Jakarta. that is; Mr. Ari Subarkah, M.Pd and 2 people who work as service judges who have BA certificate licenses, namely Saiful Bachry and Ardi Jumaryanto. 4 things are judged by experts on the service stroke height measuring device, namely: attractiveness, ease, shape/model and suitability of function. Based on the expert tests conducted, it can be concluded that measuring service stroke height using ultrasonic sensors is feasible and can be used in training or competitions.

After being assessed and evaluated by experts, the measuring tool for measuring the height of the service stroke using an ultrasonic sensor made by the researcher then takes the next step, namely testing the tool. The test was carried out at a badminton match which was held in Jakarta in December 2020. The test for measuring service stroke height using the ultrasonic sensor was used for 25 match numbers. Testing the service stroke height measuring device using an ultrasonic sensor is directly applied to the competition to see how the tool works and functions.

Also, researchers distributed questionnaires in the form of attractiveness and convenience of the tool to 25 referees and 50 men's doubles players whose matches used a service blow height measuring device using ultrasonic sensors. The results of a 
Making Service Level Measuring Equipment (Service Detector) In Badminton Sports

Ali Syafani ${ }^{1}$, Ari Subarkah $^{2}$, Ika Novitaria Marani $^{3^{*}}$

ikanovi1979@gmail.com

questionnaire on the referee/service judge on the measuring tool service stroke height using ultrasonic sensors show that the tool is $84 \%$ easy to use and $80 \%$ attractive to use. Meanwhile, the results of a questionnaire to athletes on the measuring tool service stroke height using ultrasonic sensors show that the tool is $82 \%$ easy to use and $84 \%$ attractive to use.

Based on the two results of the questionnaire from the referee/service judge and the athlete, these results indicate that the service stroke height measuring device using the ultrasonic sensor is in a good category. So, it can be concluded that the measuring tool service stroke height using ultrasonic sensors can be used. The several advantages of this tool are: (1) This tool is small and simple so it can be carried around, (2) Very easy to use, (3) The sensor is sensitive to altitude, and (4) Do not interfere with the game.

But it turns out that this product also has several weaknesses that need to be improved or refined. The weaknesses of this product are: (1) Laying the sensor pole too far from the player. Because ultrasonic sensors have limitations in the distance to be able to read an object, and (2) The sensor has unidirectional and straight-line properties. So this makes it difficult to read the position of the racket that is often moved by the player when making service hits.

Based on the product weakness analysis above, it is hoped that further research can further refine this tool by looking for sensors that have a further reading distance from the object being targeted. Or you can try it by using an application that was made by yourself so that when the player protests the service judge's decision, the player can see directly the results of the recorded service blows that were performed. With the existence of a height measuring device using an ultrasonic sensor, it is hoped that the service judge officer does not need to hesitate to decide whether the player commits a violation when carrying out a service stroke or not. And for players, an altitude meter using an ultrasonic sensor is a fair decision. Because decisions made by service judges in plain sight are often subject to long debates between athletes and referees. Because players usually do not feel that their racket is violating the allowable height limit. So that the results stated based on the height measuring device can also make the game time shorter, because the player will accept the existing decisions.

Based on the shuttlecock speed, badminton is the fastest racket sport along with tennis and squash (Teu, Kim, Tan, \& Fuss, 2005). Research on the analysis of sports movements especially in badminton in two decades is qualitative. However, now athletes' movement analysis is more mature thanks to technological advances with the use of 
Making Service Level Measuring Equipment (Service Detector) In Badminton Sports

Ali Syafani ${ }^{1}$, Ari Subarkah $^{2}$, Ika Novitaria Marani $^{3^{*}}$

ikanovi1979@gmail.com

acquisition sensors and hardware such as computers (Tan, Ting, \& Lau, 2017). Human movement analysis is a study of methods and applications generated by cameras or sensors, digitally processed to produce information (Kiang, Yoong, \& Spowage, 2009). Therefore, this research makes a tool to measure the service stroke height using an ultrasonic sensor.

The reason for making a service shot height measuring device is because the service shot is one of the basic techniques in badminton and is the first ball stroke which is very decisive in being able to get points and win a match. There are several types of service in badminton that have unique ways and have their advantages and disadvantages (Susilo, 2018). The shuttlecock being hit must attempt to fall perpendicularly downwards somewhere on the backline of the opposing court primarily directed at the corners of the intersection between the margins for single play and the backline for single play service and the intersection of the center line and backline for single-game service. Thus, the ball is more difficult to predict the fall and difficult to hit so that the opponent's return is less effective (Zhang et al., 2013).

During the match, rules are governing how to serve. This means that there are rules that must be obeyed by the player when making a serve stroke. The person who has the authority to supervise the implementation of the service is the service judge or service judges. Even for this matter of service, the service judge has the highest authority and the decision cannot be contested even by the referee. The service judge, when supervising the service in a competition, must have the courage to determine and decide quickly and precisely according to the rules. The basis for making service judges' decisions is the game rules, especially the service rules. If the service judge does not master his job or does not dare to decide whether a player's service is legitimate or not, then there is a high probability that the match will go awry and hinder the success of the championship. Therefore it is necessary to prepare professional service judges with qualifications and have the courage to declare a fault if the service is not valid. Currently, usually, the service judge officer is concurrently the referee/umpire in turns.

One of the events that must be decided by the service judge, whether the player commits a violation or not while serving, namely: the position of the racket and the racket's imposition when hitting the shuttlecock. The latest badminton game rules regarding service performance issued by the BWF are related to the height of the racket head when hitting the shuttlecock. The height allowed is $115 \mathrm{~cm}$. Of course, measuring the service level limit by using the naked eye is very difficult. Therefore, researchers are 
Making Service Level Measuring Equipment (Service Detector) In Badminton Sports

Ali Syafani ${ }^{1}$, Ari Subarkah $^{2}$, Ika Novitaria Marani ${ }^{3^{*}}$

ikanovi1979@gmail.com

interested in making a height instrument using ultrasonic sensors. With the existence of a height measuring device using an ultrasonic sensor, it is hoped that the service judge officer does not need to hesitate to decide whether the player commits a violation when carrying out a service stroke or not. And for players, an altitude meter using an ultrasonic sensor is a fair decision. Because decisions made by service judges in plain sight are often subject to long debates between athletes and referees. Because players usually do not feel that their racket is violating the allowable height limit. So that the results stated based on the height measuring device can also make the game time shorter, because the player will accept the existing decisions.

\section{CONCLUSIONS AND SUGGESTIONS}

Based on the data obtained from the results of field trials and discussion of research results, it can be concluded that: the service stroke height measuring device using ultrasonic sensors is suitable for use in badminton matches to help service judges in making decisions whether the service hit is a fault or not. The feasible results of this tool are obtained based on the validation test which is carried out using the expert justification test. And based on the results of field trials, shows that measuring service stroke height using ultrasonic sensors is attractive and easy to use. The suggestion for further research is to continue to develop the use of technology to support the improvement of badminton branch achievement, one of which is service stroke, perhaps using tools that are more sensitive to distance and human movement.

\section{REFERENCES}

Akbar, A., \& Hastjarjo, T. D. (2019). Kohesivitas Tim dan Sikap terhadap Kepemimpinan Wasit sebagai Prediktor Kecenderungan Perilaku Agresif Pemain Sepakbola. Gadjah Mada Journal of Psychology (GamaJoP), 4(1), 42. https://doi.org/10.22146/gamajop.45402

Alhusin, S. (2007). Gemar Bermain Bulutangkis. Surakarta:CV Setiaji.

Cabello Manrique, D., \& González-Badillo, J. J. (2003). Analysis of the characteristics of competitive badminton. British Journal of Sports Medicine, 37(1), 62-66. https://doi.org/10.1136/bjsm.37.1.62

Candra, A. N. (2015). Hubungan Tingkat Kepercayaan Diri (Self Confidence) Atlet Ganda Dengan Hasil Pukualn Servis Pendek (Short Service) Dalam Cabang Olahraga Bulutangkis Universitas Pendidikan Indonesia. Bandung: Universitas Pendidikan Indonesia. 
Making Service Level Measuring Equipment (Service Detector) In Badminton Sports

Ali Syafani ${ }^{1}$, Ari Subarkah $^{2}$, Ika Novitaria Marani $^{3^{*}}$

ikanovi1979@gmail.com

Downward, P., \& Jones, M. (2007). Effects of crowd size on referee decisions: Analysis of the FA Cup. Journal of Sports Sciences, 25(14), 1541-1545. https://doi.org/10.1080/02640410701275193

Eric Gillet, David Leroy, Regis Thouvarecq, and J.-F. S. (2009). A Notational Analysis of Elite Tennis Serve and Serve-Return Strategies on Slow Surface, (2), Illet, E R I C G.

Grice, T. (2007). Bulutangkis: Petunjuk Praktis Untuk Pemula dan Lanjut. Departemen Pendidikan Dan Kebudayaan Direktorat Jenderal Pendidikan Tinggi Proyek Pembinaan Tenaga Kependidikan: Jakarta.

Kiang, C. T., Yoong, C. K., \& Spowage, A. C. (2009). Local sensor system for badminton smash analysis. 2009 IEEE Intrumentation and Measurement Technology $\begin{array}{llll}\text { Conference, } & \text { I2MTC 8009, (May), }\end{array}$ https://doi.org/10.1109/IMTC.2009.5168575

Laffaye, G., Phomsoupha, M., \& Dor, F. (2015). Changes in the game characteristics of a badminton match: A longitudinal study through the olympic game finals analysis in men's singles. Journal of Sports Science and Medicine, 14(3), 584-590.

Marani, A. S. dan I. N. (2020). Analisis Teknik Dasar Pukulan Dalam Permainan Bulutangkis. Jurnal Menssana, 5(2), 96-105. Retrieved from http://menssana.ppj.unp.ac.id/index.php/jm/article/view/145/132

Purnama, S. K. (2010). Kepelatihan Bulutangkis Modern. Surakarta: Yuma Pustaka.

Subardjah, H. (2002). Bulutangkis. Jakarta: Dirjen Pendidikan Dasar dan Menengah.

Susilo, W. A. (2018). Tingkat Keterampilan Service Pendek dan Service Panjang Dalam Permainan Bulutangkis Siswa Kelas V Sekolah Dasar Muhammadiyah Bodon Tahun Ajaran 2018/2019. Universitas Negeri Yogyakarta. https://doi.org/10.22201/fq.18708404e.2004.3.66178

Tan, D. Y. W., Ting, H. Y., \& Lau, S. B. Y. (2017). A review on badminton motion analysis. Proceedings of 2016 International Conference on Robotics, Automation and Sciences, ICORAS 2016, 2-5. https://doi.org/10.1109/ICORAS.2016.7872604

Teu, K. K., Kim, W., Tan, J., \& Fuss, F. K. (2005). Using dual Euler angles for the analysis of arm movement during the badminton smash. Sports Engineering, 8(3), 171-178. https://doi.org/10.1007/bf02844017

Tohar. (2005). Olahraga Pilihan Bulutangkis. JIKIP Semarang. Semarang.Nasution, .

Zhang, B., Li, F., \& Jiang, W. (2013). Mixed Doubles Match Technical and Tactical Analysis of World Badminton Champion Based on Mathematical Statistics. Advances in Physical Education, 03(04), 154-157. https://doi.org/10.4236/ape.2013.34025 